\title{
Selection for Earliness in Bread Wheat (Triticum aestivum L.) under Infertile Soil Conditions
}

\author{
M. S. Hassan \\ Department of Agronomy, Faculty of Agriculture, South Valley \\ University, Qena, Egypt.
}

\begin{abstract}
7 HE CURRENT research was performed during the four growing seasons 2010/2011-2013/2014 at the Experimental Farm of the Agronomy Department, Faculty of Agriculture, South Valley University, Qena. This research aimed to study the response to direct selection for early heading date and the correlated response of other studied characters. Two cycles of pedigree selection for early heading date were practiced on a segregating population of bread wheat cross (SHORAWAKI BW-20313 × IG 41897 ICBW 201657) in $F_{3}$ and $F_{4}$ generations.
\end{abstract}

Results revealed highly significant difference among $\mathrm{F}_{3}$ families for heading date and the other correlated characters. Also little differences were observed between PCV and GCV values, reflecting presence of sufficient amount of genetic variability for selection. Moreover, high estimate of broad sense heritability was observed in heading date $(81.52 \%)$ in base population. After two cycles of pedigree selection for early heading date, the realized gains recorded -22.22 and $-30.36 \%$ decrease in days to heading relative to the bulk sample and better parent, respectively. Negative genotypic correlations between heading date and the other studied characters except for spike length ranged from small to moderate were observed in the base population. However, after two cycles of selection, the correlation direction was inverted, and high positive correlations between heading date and each of 100-kw and grain yield/plant $(0.80$ and 0.53$)$ were observed. Pedigree selection for early heading date resulted nine earliest families and three from them no. 2,33 and 44 taking top rank by 58.67 day. The earliest family no. 44 could be considered the best selected family because it showed 8.62 and $53.66 \%$ increase in grain weight over the better parent and the bulk sample, respectively.

Keywords: Bread wheat, Pedigree selection, Early heading date, Grain yield, Realized gains.

Wheat growth season often extends in Egypt to end of April, this increases the probability of exposure of plants to high temperature in ripening stag. Exposure to high temperature, especially in milky and mealy ripe stages and before hardness of kernels, will lead to decreased grain weight and quality of grains. Kherialla et al. (2001) found that undesirable effect of exposure to high temperature during grain filling is a major environmental factor which drastically reduces wheat production in Upper Egypt. Furthermore, exposure to high 
temperature during floral initiation and spikelet development causes reduction in potential number of grains (Ali, 2011). Cultivars with early heading date are desirable, because of their ability in escaping from drought, heat stress, disease, pests and other stress at the end of the growing season (Menshawy, 2007). In Egypt, whereas there is a big gap between wheat production and demand for consumption, early heading date can be considered as one of the important tools, that contribute in solving this problem by increasing grain yield. On the other hand, early harvesting of wheat, will lead to early sowing of summer crops, especially corn. Since, most of wheat planting area in Upper Egypt is followed by corn crop. An early wheat harvesting increases the chances of obtaining a good yield of corn and twice cultivations in the same season, which duplicates the total production. Aglan \& Farhat (2014) denoted that early maturing cultivars aid to fit in crop intensive rotation in Egypt. So development of wheat cultivars with early maturing and without decrease in grain yield is a main objective of many wheat breeding programs. Allard \& Harding (1963), Avey et al. (1982) and Frederickson \& Kronstad (1985) reported that heading date in wheat is an easily identifiable character that can be modified through selection. Decrease in plant height, 1000-grain weight and grain yield/plant were noticed with two cycles of direct selection for earliness under early and late planting (Tammam et al., 2004; Zakaria, 2004 and El-Morshidy et al., 2010). May \& Van Sanford (1992) mentioned that direct response to selection for early heading date were 5 and 10 days in two populations, respectively. High estimates of heritability for days to heading, 1000-grain weight and grain yield/plant were found under normal and stress conditions by El-Shazly et al. (2000) and Attia (2003). Iqbal et al. (2006), Erkul et al. (2010) and El-Fadly et al. (2013) reported that the expected genetic advance from selection was found to be low to moderate for days to heading and maturity. The purpose of this research was to study the response to direct selection for early heading date and investigate the correlated response of the other studied characters under infertile soil conditions in Upper Egypt.

\section{Materials and Methods}

Experimental site description

This research was carried out during four growing seasons, 2010/20112013/2014 at the Experimental Farm of South Valley University, Qena, Egypt $\left(26^{\circ} 11^{\prime} \mathrm{N}\right.$ and $\left.32^{\circ} 44^{\prime} \mathrm{E}\right)$. Soil of the Experimental Farm is newly reclaimed lands irrigated by saline underground water $\left(7.71 \mathrm{ds} \mathrm{m}^{-1}\right)$. So, it could be considered as infertile soil. Some soil properties of the experimental site are shown in Table 1.

TABLE 1. Pedigree and origin of the parental wheat genotypes.

\begin{tabular}{|l|c|c|}
\hline Parents & Pedigree & Origin \\
\hline P1 & SHORAWAKI BW-20313 & Mexico \\
\hline P2 & IG 41897 ICBW 201657 & $\begin{array}{c}\text { ICARDA } \\
\text { (origin country: Morocco) }\end{array}$ \\
\hline
\end{tabular}

Egypt. J. Agron . 36, No.2 (2014) 
Selection practices

The population used in the current study was the $\mathrm{F}_{2}$ generation of the cross: SHORAWAKI BW-20313 × IG 41897 ICBW 201657. The pedigree and origin of the two parents are presented in Table 2 . In the first season, 500 plants from $F_{2}$ generation were sown individually on $19^{\text {th }}$, November 2010 in nonreplicated trial of two plots. Each plot consisted of 10 rows, $3 \mathrm{~m}$ long, $20 \mathrm{~cm}$ apart and $15 \mathrm{~cm}$ between hills within row (average 20 plants/row). Also, the parents were sown alongside each row. Heading date for an individual plant was defined as the day of complete spike emergence from the flag leaf sheath. One hundred plants, which headed earliest were selected and harvested. From them, 25 highest grain yielding plants were selected to give $\mathrm{F}_{3}$-families $(5 \%$ selection intensity).

TABLE 2. Some physical and chemical properties of the experimental site (average all growing seasons).

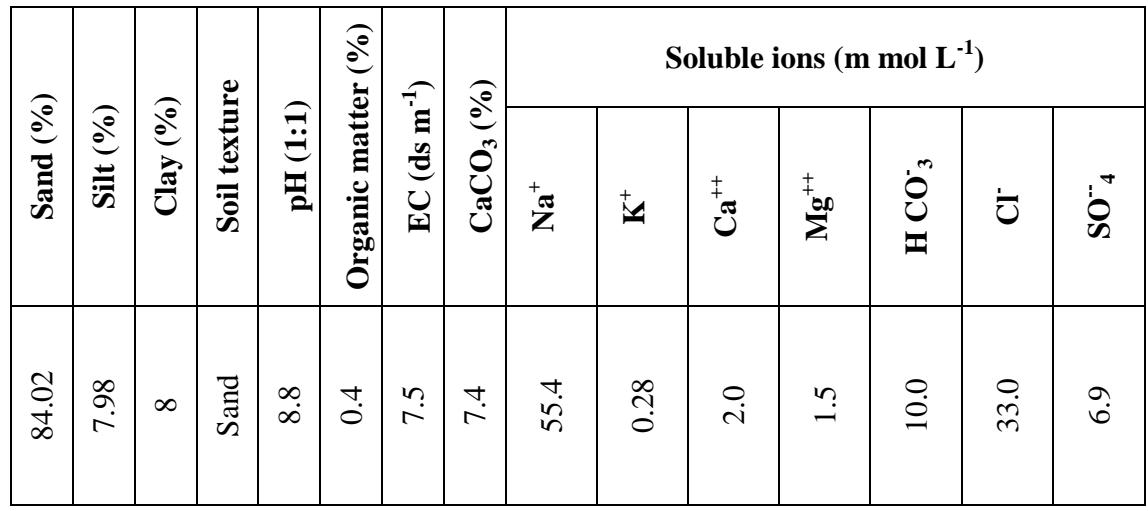

An equal number of grains were composited from each $F_{2}$ plants to give $F_{3}$ bulk sample.

In the second season, the $25 \mathrm{~F}_{3}$-families parents and $\mathrm{F}_{3}$ bulk random sample were sown on Nov. $21^{s t}$ with three replications in a randomized complete blocks design (RCBD). Plants were sown on the following basis, each family, bulk sample and parents were sown in a single row, $3 \mathrm{~m}$ long $20 \mathrm{~cm}$ apart and $15 \mathrm{~cm}$. between hills in each replicate. The earliest 10 plants in heading date in each row were selected and harvested. Heading date was recorded as a number of days to heading of $50 \%$ of plants in each row. In addition, data of plant height (PH), spike length (SL), no. of spikelets/spike, 100-kernel weight (SI) and grain yield/plant (GY) were measured on the ten selected plants. Means of these ten plants were subjected to the statistical and genetic analysis. The best plant in grain yield from each of the earliest fifteen families in heading date was selected to give $\mathrm{F}_{4}$-families (60\% selection intensity). Next season, the 15 families, parents and $\mathrm{F}_{4^{-}}$bulk random sample were planted on $21^{\text {st }}$, November. The experimental design, number of replications, recorded data and selection were practiced as in the previous season. For the second cycle of selection, the best 
plant in grain yield from each of the earliest nine families in heading date was selected to give $\mathrm{F}_{5^{-}}$families ( $60 \%$ selection intensity).The $\mathrm{F}_{5}$ selected families, parents and bulk sample were planted on $25^{\text {th }}$, November, 2013. The experimental design, number of replications, recorded data were practiced as in the previous season. The cultural practices for wheat production were applied during all the growing seasons according to the recommendations of the Ministry of Agriculture.

\section{Statistical analysis}

Analysis of variance of RCBD was performed according to Snedecor \& Cochran (1980). Significance of differences between means in $F_{5}$ generation was tested by using the revised LSD according to El-Rawi \& Khalafalla (1980) on the basis of analysis of variance for all genotypes $\left(\mathrm{F}_{5}\right.$-selected families, parents and sample bulk). The phenotypic and genotypic coefficients of variation (PCV and GCV) were calculated according to Singh \& Chaudhary (1985). Estimates of broad sense heritability (BSH) were estimated as the ratio of genotypic to phenotypic variance according to Falconer (1989). Realized response to selection was calculated as the deviation percentage of the overall mean from the better parent and bulk sample according to Falconer (1989). Genotypic correlation between heading date and each of the other studied characters in base population and the two cycles of selection were measured according to Miller et al. (1958).

\section{Base population}

\section{Results and Discussion}

Analysis of variance presented in Table 3 revealed highly significant differences between $\mathrm{F}_{3}$ families for heading date and the correlated characters. These results indicate to the presence of sufficient variability to practice of selection. Phenotypic coefficients of variation (PCV) showed $5.67 \%$ for heading date and ranged from 10.75 to $25 \%$ in the correlated characters (Table 3). In addition, genotypic coefficients of variation (GCV) for heading date were $5.12 \%$ and ranged in the correlated characters from 8.92 to $22.5 \%$ (Table 3). The high values of GCV indicate the presence of sufficient genetic variability for further improvement. Little differences were observed between PCV and GCV values, indicating the importance of the genetic effects in inheritance of the characters. High estimate of broad sense heritability was observed in heading date $(81.52 \%$ ), and ranged from 65.25 to $81.33 \%$ in the correlated characters (Table 3). These results indicated that heading date was mostly controlled by genetic factors and less affected by the environment conditions. Burton (1952) and Sanghi et al. (1964) revealed that genetic coefficient of variation together with heritability estimate would seem to give the best picture of the a mount of genetic advance from selection. Generally all the previous results reflect suitable of this base population to practice the direct selection for earliness. The obtained results were in agreement with those reported by Benmoussa \& Achouch (2005), Shamroukh (2006), El-Morshidy et al. (2010), Ali (2011) and El-Ameen (2013).

Egypt. J. Agron . 36, No.2 (2014) 
TABLE 3. Mean squares, phenotypic \& genotypic coefficients of variability and heritability for all the studied characters of $F_{3}$ selected families (base population).

\begin{tabular}{|c|c|c|c|c|c|c|c|}
\hline \multirow{2}{*}{$\begin{array}{c}\text { Source of } \\
\text { variation }\end{array}$} & \multirow{2}{*}{$\begin{array}{c}\text { Degrees } \\
\text { of } \\
\text { freedom }\end{array}$} & $\begin{array}{c}\text { Direct } \\
\text { selection }\end{array}$ & \multicolumn{5}{|c|}{ Indirect selection } \\
\cline { 3 - 8 } & & $\begin{array}{c}\text { Heading } \\
\text { date } \\
\text { (days) }\end{array}$ & PH (cm) & $\begin{array}{c}\text { SL } \\
\text { (cm) }\end{array}$ & $\begin{array}{c}\text { No. of } \\
\text { spikelets/ } \\
\text { spike }\end{array}$ & SI (gm) & $\begin{array}{c}\text { GY } \\
\text { (gm) }\end{array}$ \\
\hline Reps. & 2 & 2.65 & 16 & 3.17 & 1.56 & 0.10 & 0.01 \\
\hline $\begin{array}{l}\text { Selected } \\
\text { families }\end{array}$ & 24 & $42.55^{* *}$ & $241.52^{* *}$ & $8.69^{* *}$ & $9.50^{* *}$ & $0.61^{* *}$ & $0.42^{* *}$ \\
\hline Error & 48 & 2.99 & 17.17 & 1.31 & 1.27 & 0.02 & 0.03 \\
\hline Better parent & 81 & 75 & 11.4 & 22 & 3.86 & 2.70 \\
\hline Bulk sample & 76 & 55 & 8.2 & 17 & 3.54 & 2.56 \\
\hline PCV (\%) & & 5.67 & 14.36 & 20.55 & 10.75 & 12.34 & 25 \\
\hline GCV (\%) & 5.12 & 12.95 & 16.63 & 8.92 & 11.81 & 22.5 \\
\hline BSH (\%) & 81.52 & 81.33 & 65.25 & 68.33 & 90.91 & 81.25 \\
\hline
\end{tabular}

** Significant at 0.01 probability level

\section{Selection response}

Mean heading date was earlier by 6 and 11 days after one and two cycles of pedigree selection, respectively compared to the $\mathrm{C}_{0}$ (Table 4$)$. Results presented in Table 4 indicate realized gains from selection for earliness corresponding to (-16.5 and $-18.59 \%)$ and $(-22.22$ and $-30.36 \%)$ decrease in days to heading relative, respectively to the bulk sample and better parent after one and two cycles of selection. Thus it could be said that, selection for earliness succeeded in decreasing days to heading. These results are in the line with those obtained in other studies (Avey et al., 1982, Frederickson \& Kronstad, 1985 and Ali, 2011). Moreover, ElAmeen (2013) found that the realized gains for early heading date were 9.41, 10.50 and $15.21 \%$ in the $1^{\text {st }}, 2^{\text {nd }}$ and $3^{\text {rd }}$ cycle of selection, respectively.

It is also noticed that progress in early heading date after the first cycle of selection was approximately equal to that achieved after the second cycle (6 and 5 days, respectively). This may be due to equal selection intensity in the two cycles (60 \%). In contrast, Avey et al. (1982), Frederickson \& Kronstad (1985) and May \&Van Sanford (1992) found that progress for early heading date in the first cycle of selection was greater than that in the second one. With respect to the correlated response to reduce days to heading, all studied 
characters were increased relative to the bulk sample (Table 4). In addition, responses of all studied characters except for no. of spikelets/spike were also increased relative to the better parent after one cycle of selection. These results may be due to the selection procedure, the best plants in grain yield from the earliest plants in heading date being selected in each cycle. However after two cycle of selection, responses of all studied characters except for plant height were reduced. Similar results were obtained by El-Ameen (2013) who reported that the observed correlated responses to selection for heading date in 1000-grain weight, no. of grains, spike length and grain yield over the bulk sample were significant and positive.

In contrast, Ali (2011) revealed that negative correlated responses in plant height, spike length 1000- grain weight and grain yield/plant by selecting for earliness of heading date.

TABLE 4. Means and realized gains $(\mathrm{Rg}) \&$ correlated responses to selection for early heading measured in percentage from bulk sample and the better parent.

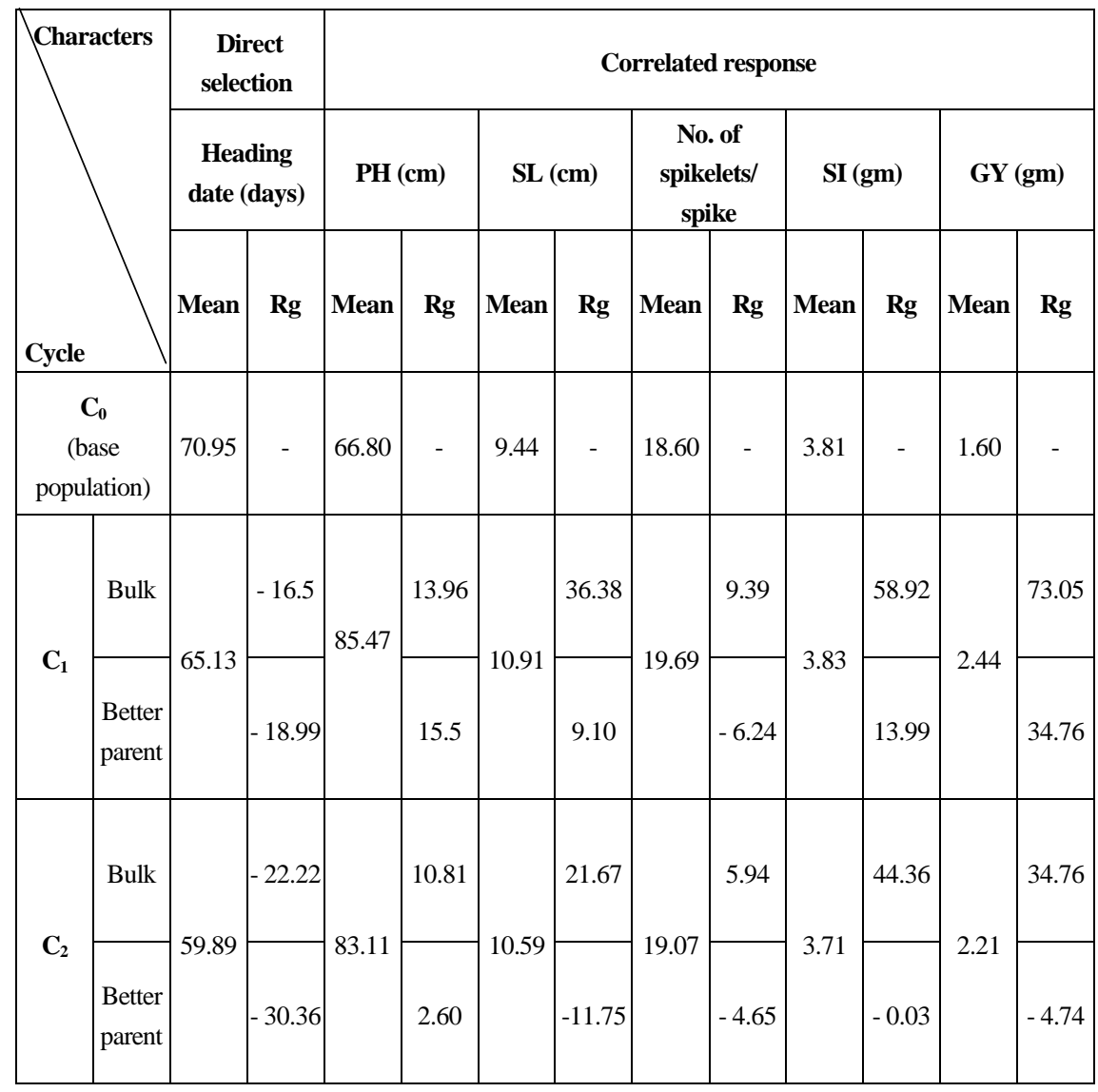

Egypt. J. Agron . 36, No.2 (2014) 


\section{Genotypic correlation}

Data of genotypic correlation between heading date and the other studied characters in the base populations and the two cycles of pedigree selection are presented in Table 5. Negative coefficients of genotypic correlation ranged from small to moderate are observed in the base population. With exception of plant height and spike length, the same direction of correlation is still found after one cycle of pedigree selection. However, after two cycles of selection the direction was inverted for all studied characters. For example, high positive correlations between heading date and each of $100-\mathrm{KW}$ and grain yield/plant $(0.80$ and 0.53$)$ were observed. These obtained results mean that these studied characters could be improved as an indirect response to direct selection for early heading date. This finding support and interpret the positive correlated responses of most of the studied characters to decreased days to heading from bulk sample after two cycles of pedigree selection in our study. In this concern, El-Ameen (2013) found positive correlation between heading date and each of grain yield, 1000grain weight and spike length in $1^{\text {st }}$ and $2^{\text {nd }}$ cycles of selection except for spike length in $2^{\text {nd }}$ cycle which has negative correlation. In contrast, Mahmoud (2007) indicated that genotypic correlation between grain yield/plant and heading date shifted from positive correlation $(0.35)$ after one cycle to negative correlation $(-0.20)$ after two cycles of pedigree selection.

TABLE 5. Coefficients of genotypic correlation between heading date and each of the other studied characters in base population and the two cycles of selection.

\begin{tabular}{|l|c|c|c|c|c|}
\hline Cycle & PH (cm) & SL (cm) & $\begin{array}{c}\text { No. of } \\
\text { spikelets/ } \\
\text { spike }\end{array}$ & SI (gm) & GY (gm) \\
\hline $\begin{array}{l}\mathbf{C}_{0} \\
\text { (base population) }\end{array}$ & -0.31 & 0.20 & -0.18 & -0.53 & -0.26 \\
\hline $\mathbf{C}_{1}$ & 0.34 & 0.06 & -0.09 & -0.34 & -0.12 \\
\hline $\mathbf{C}_{2}$ & 0.31 & -0.55 & 0.13 & 0.80 & 0.53 \\
\hline
\end{tabular}

Performance of superior selections

Performance of the nine superior selected families after two cycles of pedigree selection for early heading date with the bulk sample and parents are presented in Table 6 . It is clear from these results superiority of these nine selected families in early heading date compared to the bulk sample and the two parents. It is also noticed that overall family mean were ranged from 58.6762.67 day. Among them the families' no. 2, 33 and 44, took top rank in early heading date by 58.67 day. Decreases in days to heading relative to the better 
parent and the bulk sample are -31.78 and $-23.81 \%$, respectively. In addition the earliest family no. 44 recorded 8.62 and $53.66 \%$ increase in grain weight over the better parent and bulk sample, respectively. So, it could be considered the best selected family. Mostly, the nine selected families had a good performance in the other correlated characters. Thus, it could be concluded that two cycles of pedigree selection for early heading date resulted in nine earlier families with good performance in yielding ability. These results are in harmony with those obtained by Kheiralla et al. (2001), Zakaria (2004), Ali (2011) and El-Ameen (2013).

TABLE 6. Mean performance of the nine selected families after the two cycles of pedigree selection for early heading date, parents and bulk sample.

\begin{tabular}{|c|c|c|c|c|c|c|c|}
\hline \multirow{2}{*}{$\begin{array}{c}\text { Selected } \\
\text { families }\end{array}$} & & Direct & \multicolumn{5}{|c|}{ Correlated response } \\
\hline & & $\begin{array}{c}\text { Heading } \\
\text { date } \\
\text { (days) }\end{array}$ & PH (cm) & $\begin{array}{c}\text { SL } \\
(\mathbf{c m})\end{array}$ & $\begin{array}{c}\text { No. of } \\
\text { spikelets/ } \\
\text { spike }\end{array}$ & $\begin{array}{c}\text { SI } \\
(\mathbf{g m})\end{array}$ & $\begin{array}{l}\text { GY } \\
\text { (gm) }\end{array}$ \\
\hline 1 & & 60.00 & 88.00 & 9.33 & 17.67 & 3.44 & 2.17 \\
\hline 2 & & 58.67 & 74.67 & 11.67 & 21.00 & 3.74 & 2.02 \\
\hline 24 & & 59.00 & 85.00 & 12.67 & 21.67 & 3.33 & 1.11 \\
\hline 31 & & 62.67 & 81.00 & 9.00 & 19.00 & 4.25 & 2.11 \\
\hline 33 & & 58.67 & 79.00 & 8.67 & 16.00 & 3.35 & 1.70 \\
\hline 38 & & 60.67 & 85.67 & 10.67 & 18.00 & 3.81 & 2.55 \\
\hline 44 & & 58.67 & 87.00 & 13.00 & 18.00 & 2.83 & 2.52 \\
\hline 47 & & 61.67 & 87.00 & 9.67 & 20.67 & 4.53 & 3.62 \\
\hline 53 & & 59.00 & 80.67 & 10.67 & 19.67 & 4.07 & 2.07 \\
\hline Parent 1 & & 88.00 & 81.00 & 12.00 & 17.00 & 2.37 & 1.05 \\
\hline Parent 2 & & 86.00 & 77.00 & 8.00 & 20.00 & 3.72 & 2.32 \\
\hline Bulk & & 77.00 & 75.00 & 9.00 & 18.00 & 2.57 & 1.64 \\
\hline $\begin{array}{c}\text { Revised } \\
\text { L.S.D. }\end{array}$ & $\begin{array}{c}\text { at } \\
5 \%\end{array}$ & 1.17 & 2.57 & 1.17 & 1.34 & 0.26 & 0.30 \\
\hline
\end{tabular}

Egypt. J. Agron . 36, No.2 (2014) 


\begin{tabular}{|c|c|c|c|c|c|c|c|}
\hline & $\begin{array}{c}\text { at } \\
1 \%\end{array}$ & 1.56 & 3.42 & 1.56 & 1.80 & 0.34 & 0.39 \\
\hline
\end{tabular}

\section{Conclusion}

From the results of this study, it can be concluded that pedigree selection for early heading date was effective in decreasing number of days to heading. Furthermore, the two cycles of selection resulted in nine earlier genotypes with good performance in yielding ability, these genotypes can be used in improvement wheat production.

\section{References}

Aglan, M. A. and Farhat, W. Z. E. (2014) Genetic studies on some earliness and agronomic characters in advanced generations in bread wheat (Triticum aestivum L.). International Journal of Plant \& Soil Science, 3 (6), 790-798.

Ali, M. A. (2011) Response to pedigree selection for earliness and grain yield in spring wheat under heat stress. Asian Journal of Crop Science, 3 (3), 118-129.

Allarad, R. W. and Harding, J. (1963) Early generation analysis and prediction of gain under selection in derivatives of a wheat hybrid. Crop Sci. 3, 454-456.

Attia, I. A. (2003) Selection for drought tolerance in wheat. Ph. D. Thesis, El-Minia University, Egypt.

Avey, D. P., Ohm, H. W., Patterson F. L. and Nyquist, W. E. (1982) Three cycles of simple recurrent selection for early heading in winter wheat. Crop Sci. 22, 908-912.

Benmoussa, M. and Achouch (2005) Effect of water stress on yield and its components of some cereals in Algeria. J. Cent. Eur. Agric. 6, 427-434.

Burton, G.W. (1952) Quantitative inheritance in grasses. Proc. $6^{\text {th }}$ Int. Grassland Congr., 1, 277-283.

El Ameen, Th. (2013) Selection for early heading in bread wheat and correlated response in yield attributes. Egypt. J. Plant Breed. 17 (3),23-32.

El-Fadly, G.A.B., Hagras, A. A. and Abd El-Khalik, S.A.M. (2013) Genetical studies on earliness characters and grain yield in some bread wheat crosses. J. Agric. Res. Kafrelsheikh Uni. 39 (2).

El-Morshidy, M.A., Kheiralla, K.A., Ali, M.A. and Ahmed, A.A.S. (2010) Efficiency of pedigree selection for earliness and grain yield in two wheat populations under water stress conditions. Assiut J. Agric. Sci. 37, 77-94.

El-Rawi, K. and Khalafalla, A.M. (1980) "Design and Analysis of Agricultural Experiments". El-Mousel University, Iraq, pp. 19. 
El-Shazly, M. S., El Ashry, M. A., Nachit, M. and El- Sebae, A. S. (2000) Performance of selected durum wheat genotypes under different environment conditions in Eastern Egypt. Proceedings of a Seminar on Durum Wheat Improvement in Mediterranean Region: New Challenges, Apr. 12-14, Zaragoza, Spain, pp.595-600.

Erkul, A., Ünay, A. and Konak, C. (2010) Inheritance of yield and yield components in bread wheat (Triticum aestivum L.) cross. Turkish J. of Field Crops, 15(2), 137-140.

Falconers, D.S. (1989) "Introduction to Quantitative Genetics". ( $3^{\text {rd }}$ ed) Longman Scientific and Technical, Longman House, Burnt Mill, Harlow, Essex, England.

Frederickson, L. J. and Kronstad, W. E. (1985) A comparison of intermating and selfing following selection for heading date in two diverse winter wheat crosses. Crop Sci. 25, 555-560.

Iqbal, M., Navabi, A., Salmon, D. F., Yang rong cai and Spaner, D. A. (2006) A genetic examination of early flowering and maturity in Canadian spring wheat. Canadian J. of Plant Science, 86(4), 995-1004.

Kheiralla, K. A., El-Morshidy, M. A. and Zakaria, M. M. (2001) Inheritance of earliness and yield in bread wheat under favorable and late sowing dates. Proceedings of the $2^{\text {nd }}$ Plant Breeding Conference, Oct. $2^{\text {nd }}$, Assiut University, Egypt, pp. 219-240.

Mahmoud, A. M., (2007) Late and early pedigree selection for grain yielding with different selection criteria under two water treatments in wheat (Triticum aestivum L.). Egypt. J. Plant Breed. 11 (2): 611-625.

May, L. and Van Sanford, D. A. (1992) Selection for early headings and correlated response in maturity of soft red winter wheat. Crop Science, 32, 47-51.

Menshawy, A.M.M. (2007) Evaluation of some early bread wheat genotypes under different sowing dates: 2. Agronomic characters. Egypt. J. Plant Breed. 11, 41-55.

Miller, P.A., Williams. Jr, J.C. Robison, H.F. and Comostock, R.E. (1958) Estimates of genotypic and environmental variances and covariances in upland cotton and their implications in selection. Agronomy Journal, 50, 126-131.

Sanghi, A.K., Bhatnagar, M.P. and Sharm, S. K. (1964) Genotypic and phenotypic variability in yield and other quantitative character in guar. Indian J. gent. Plant Breed. 29, 164-167.

Singh, R.K. and Chaudhary, B.D. (1985) "Biometrical Methods in Quantitative Analysis". Kalayanic Publishers. New Delhi.

Shamroukh, M. (2006) Breeding for drought tolerance in bread wheat under new land condition in Upper Egypt. Ph.D. Thesis, Minia University, Egypt. 
Snedecor, G.W. and Cochran, W.G. (1980) "Statistical Methods". $7^{\text {th }}$ ed., Iowa State University Press, Iowa, USA., ISBN-10:0-81381560-6, pp. 507.

Tammam, A. A. M., El-Ashmoony, M. S. F., El-Sherbeny, A. A. and Amin, L. A. A. (2004) Selection responses for drought tolerance in two bread wheat crosses. Egypt. J. Agric. Res. 82, 1213-1226.

Zakaria, M. M. (2004) Selection for earliness and grain yield in bread wheat (Triticum aestivum L.) under different environments. Ph.D. Thesis. Assuit University, Egypt.

(Received 14/8/2014; accepted 10/9/2014)

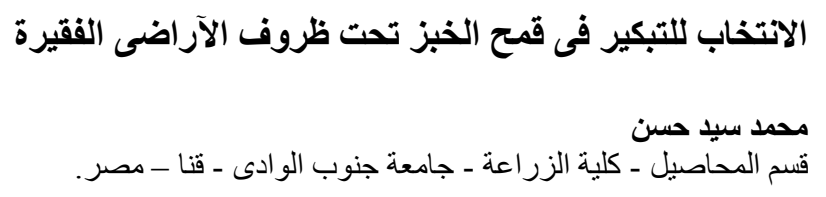

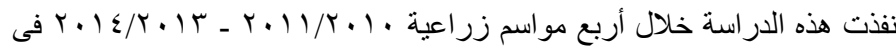

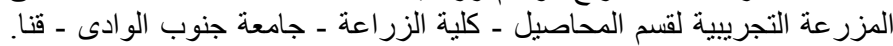

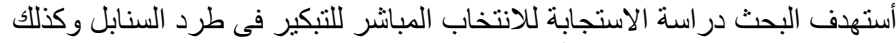

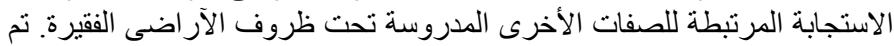

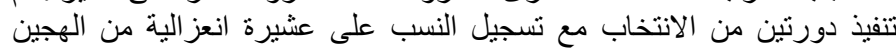
SHORAWAKI BW-20313 × IG 41897 ICBW 201657)

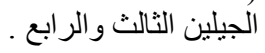

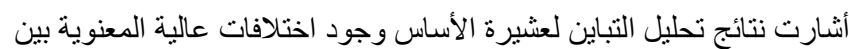

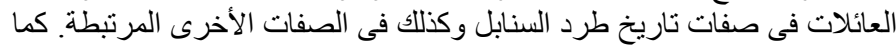

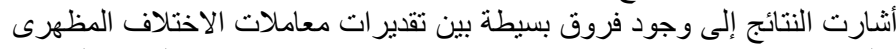

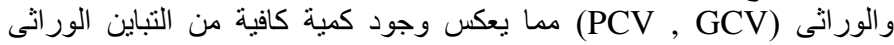

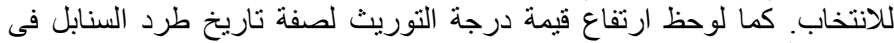

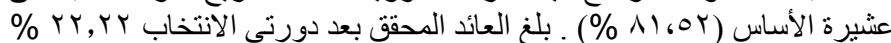

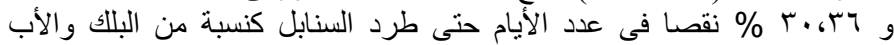

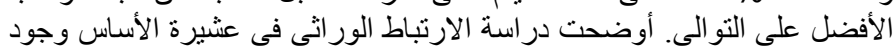

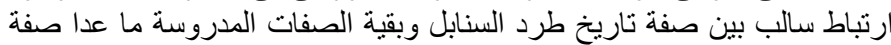

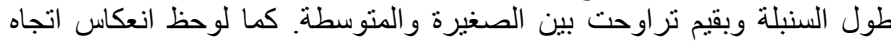

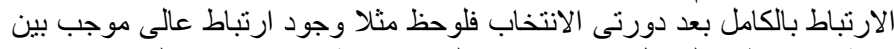

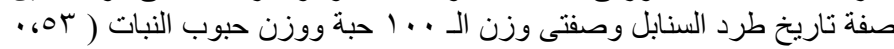

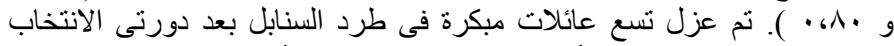

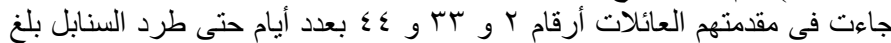

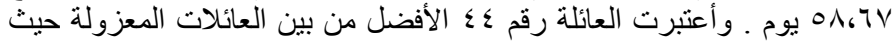

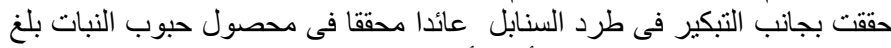

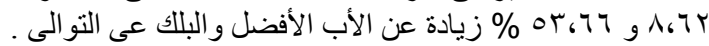

